\title{
Assessing the Impact of Work-Related Attitudes on Performance in the Private and Public Sector of Employment in Ghana
}

\author{
Abban Isaac ${ }^{1 *}$ Desmond Ofori Oklikah ${ }^{2}$ \\ 1.Department of Sociology \& Anthroplogy, University of Cape Coast, P. O. Box C/o 480 Swedru, Ghana. \\ 2. Department of History, University of Guelph, 15 College Avenue West, Guelph, Ontario N1G 1R7.
}

\begin{abstract}
This paper examines employee attitudes and how it promotes overall performance at the workplace. The paper is an outcome from questionnaires administered to 39 respondents: teaching and non-teaching staff in the Cape Coast Metropolis in Ghana. Using Herzberg's two-factor theory, expectancy theory and theories of job satisfaction and organizational commitment, this paper sheds light on the factors that make employees develop positive work attitudes and motivation on the job, it likewise assesses the place of higher remuneration and effective supervision towards employee work attitude. The findings from the research show that employees in the private sector of employment showed higher levels of job involvement and enjoyed enormous job security than those in the public sector. In addition, supervision was effective in the private sector than in the public sector of employment. We therefore recommend the improvement in infrastructure and the provision of enabling working environment and good working conditions for efficient employee output.
\end{abstract}

Keywords: Public Sector, Private Sector, Attitudes, Performance, Expectancy Theory, Herzberg Theory, Motivation, Supervision, Employees, Environment

DOI: $10.7176 /$ RHSS/10-22-12

Publication date: November $30^{\text {th }} 2020$

\section{Introduction}

Workers in organizations put up favorable attitudes to work when well-motivated and tend to put up poor attitudes when poorly motivated resulting in low productivity. A study found that positive attitudes toward voluntary training and development activities generate intentions to engage in such activities and that these intentions are related to participation rates (Hurtz \& Williams, 2009). Work related attitudes that stifle productivity are not only unique to Ghana but could be considered a worldwide problem. In support of Newstorm \& Davis's (1993) argument that attitudes are reasonably good predictors of behaviours and provide clues to an employee's behavioural intentions or inclinations to act in a certain way, positive job attitudes help to predict constructive behaviours; negative job attitudes help to predict undesirable behaviours. When employees are dissatisfied with their jobs, they lack job involvement, and show less commitment to the organization culminating into a number of consequences. Dissatisfied employees may engage in psychological withdrawal, physical withdrawal (for example, unauthorized absences, and early departures, extended breaks, or work slowdowns), or even aggressive retaliation for presumed wrongs. In Ghana, wide disparities in productivity and efficiency exist at the public and private sectors of employment. According to (Etsey, Amedahe \& Edjah, 2005), in the study of some private and public schools in Ghana, insist that academic performance is better in private schools due to more effective supervision of work. Thus, effective supervision improves the quality of teaching and learning in the classroom (Neagley \& Evans, 1970). Also, the attitude of some public-school teachers and authorities to their duties do not engender good learning process for the pupils. Some teachers leave the classroom at will without attending to their pupils because there is insufficient supervision by circuit supervisors. This lack of supervision gives the teachers ample room to do as they please. Another factor is lack of motivation and professional commitment to work by teachers. (Young, 1989). This produces poor attendance and unprofessional attitudes towards pupils by the teachers, consequently affecting the performance of the pupils' academically (Lockheed \& Verspoor, 1991). This paper investigates some work-related attitudes that stimulate performance in the public and private sector of employment.

\section{Concepts of Job attitudes}

The substantive nature of job attitudes flows from the broader literature on social attitudes. A job attitude is a type of attitude, and therefore it is important to place job attitudes research in the broader context of social attitudes research. As noted by Olson and Zanna (1993), "despite the long history of research on attitudes, there is no universally agreed upon definition". Perhaps the most widely accepted definition of an attitude, however, was provided by Eagly and Chaiken (1993): "a psychological tendency that is expressed by evaluating a particular entity with some degree of favour or disfavour." Thus, the concept of evaluation is a unifying theme in attitudes research. One problem for attitudes research is that individuals may form an evaluation of (and thus hold an attitude about) a nearly limitless number of entities. Some of these attitudes may border on the trivial, at least in a general psychological sense.

Robbins (2003) also defined attitudes as evaluative statements that can either be favourable or unfavourable 
concerning objects, people, or events. They reflect how one feels about something. The favourable statements may provide positive effects regarding the concerned object, person or event whereas unfavorable statement may provide negative effects. An attitude is a positive or negative feeling or mental state of readiness, learned and organized through experience that exerts specific influence on a person's response to people, objects and situations. This definition of attitude has certain implications for managers. Attitudes are learned and may define one's predispositions toward given aspects of the world. Moreover, attitudes provide emotional basis of one's interpersonal relations and identification with others; and, can be organized and closed to the core of an individual's personality. Some attitudes are persistent and enduring, yet, like each of the psychological variables, attitudes are subject to change (Fishbein \& Ajzen, 1975).

\subsection{Job Performance}

Every employee working within an organization is expected to perform their job in a dependable way. Employees are expected to be responsible for successful performance of tasks and duties involved in the job according to the employment contract. Employees accept certain job assignments and agree to do them dependably. They should feel a sense of responsibility for doing their job well (Opatha, 2009). Some of the well-known definitions of job performance provide clear insight of it and they can be extensively used for this research study. According to Moorhead and Griffin (1999), job performance is made up of all work-related behaviours. Job performance is the accomplishment of those tasks that comprises a person's job. (Porter \& Lawler, 1968). It means execution of a total set of job-related tasks. The tasks that should be performed are different from one job to another. Borman and Motowidlo (1993) presented a model of job performance which reflected such behaviours that were comprehensive of job performance specialty, classified as either task or relative performance. In the performance literature, a distinction is made between a role and extra-role performance (Katz \& Kahn, 1978). Extra-role performance is also conceptualized as organizational citizenship behaviors (Smith, Organ, \& Near, 1983). Based on this research, Borman and Motowidlo (1993) suggested that performance can be divided into two parts, task and contextual performance.

\subsection{Two-Factor Theory}

Herzberg's (1959) Two-Factor Theory addresses the issue of workplace motivation. The theory introduces two factors to account for overall job satisfaction: motivators and hygiene factors. While the presence of motivators in a job can contribute to the increase in the level of satisfaction, the absence of hygiene factors in the workplace can be the cause of dissatisfaction. Hygiene factors allude to the environment and the context of the work. This can include salary, safe working conditions, among others. Motivators are related to the characteristics of the job itself. According to the theory, motivators and hygiene factors are non- exclusive. Satisfaction and dissatisfaction cannot be considered as the opposite ends of one continuum. Therefore, an increase in the level of job satisfaction does not necessarily imply a decrease in job dissatisfaction, since the elements affecting satisfaction and dissatisfaction are different. The Two- Factor is also often referred to as the Motivation-Hygiene Theory (Davies, 2008). Herzberg's theory offers an explanation to why employees still lack motivation when confronted with high salaries and great working conditions. The latter two elements only represent hygiene factors, which keep dissatisfaction at bay. According to Herzberg, motivation comes from the job itself. Therefore, it is important for managers to look into the nature of the jobs they ask their employees to do. Herzberg's reasons that for an employee to be productive, the job must be in a position to provide the basic job needs. Thus, in order to improve job attitudes and productivity, employers must attend to both factors and not assume that an increase in satisfaction leads to a consequential decrease in dissatisfaction. In consequence, Herzberg's work implies that employees will respond positively to a job with highly motivating factors.

\subsection{Expectancy theory}

Expectancy theory maintains that the power of one's propensity to act in a certain way depends on the expectation of the product of conduct or action as well as how attractive it is (Robbins \& Judge 2013). Expectancy theory is highlighted on the persuasion that employee work will result in performance and performance will lead to rewards (Vroom, Victor, Deci, \& Edward, 1964). However, expectancy theory is a cognitive procedure theory of motivation that is founded on the idea that employees perceive that there are relations between the effort they put out at work, the performance they accomplish from that effort, and the rewards they gain from their effort and performance (Lunenburg, 2011). Further, Robbins and Judge (2013) submitted that expectancy theory centers on three interactions that comprise effort- performance relationship, performance- reward relationship and personal goal relationship. Base on the study, expectancy theory, therefore, supports the assertion that the employee performs based on an expected outcome and depending on the outcome of such performance, the level of job attitude is determined. This implies that if an employee performance will lead to expected result, it will enhance job attitude thereby developing a positive attitude which will result to high level of performance of an employee. By implication higher rewards result in higher job attitude and increased performance level, whereas lower rewards 
demoralize an employee, thereby resulting to poor or negative job attitude which will bring about decreased performance (Saari, \& Judge 2004).

\subsection{Job Satisfaction}

Job satisfaction is among the important attitudes that influence human behaviour in the workplace. Thus, organizational behavior researchers are interested in accurately measuring job satisfaction and understanding its consequences for people at work (Wood \& Locke, 1976). Some of the well-known definitions of job satisfaction provide clear insight of it and they were helpful for this research study. Wood and Locke (1990) defined job satisfaction as the degree to which individuals feel positively or negatively about their jobs. It is an emotional response to one's tasks as well as to the physical and social conditions of the workplace. As a concept, job satisfaction also indicates the degree to which expectations in someone's psychological contract is fulfilled. Job satisfaction is likely to be higher for persons who perceive an inducement- contributions balance in their relationship with the employing organization. Job satisfaction is the amount of pleasure or contentment associated with a job. Workers will have high job satisfaction when they have positive attitudes toward such job factors such as the work itself, recognition and opportunity for advancement. According to Smith and Hulin (1969), job satisfaction is the extent to which a person is gratified or fulfilled by his or her work. Extensive research on job satisfaction shows that personal factors such as an individual's need and aspirations determine this attitude, along with group and organizational factors such as relationships with coworkers, supervisors, working conditions, work policies, and compensation.

Job satisfaction is referred to an individual's general attitude toward his or her job. A person with a high level of job satisfaction holds positive attitudes toward the job; a person who is dissatisfied with his or her job holds negative attitudes about the job (Robins, 2003). According to Locke and Weiss (2001), job satisfaction is a pleasurable or positive emotional state resulting from the appraisal of one's job or job experiences. Implicit in Locke's definition is the importance of both affect, or feeling, and cognition or thinking. When we think, we have feelings about what we think. Conversely, when we have feelings, we think about what we feel. Cognition and affect are thus inextricably linked, in our psychology and even in our biology (Saari \& Judge, 2004). According to Smith and Hulin (1964), job satisfaction is the extent to which a person is gratified or fulfilled by his or her work. Extensive research on job satisfaction shows that personal factors such as an individual's needs and aspirations determine this attitude, along with group and organizational factors such as relationships with coworkers, supervisors, working conditions, work policies, and compensation. Job satisfaction is referred to an individual's general attitude toward his or her job. Based on a literature review of job attitude research, Herzberg, Mausner and Snyderman (1959) developed a model of job satisfaction, which assumed that job satisfaction and dissatisfaction are not on opposite ends of a continuum but are separate attitudes. They proposed that job satisfaction and dissatisfaction are caused by different underlying job factors and cannot substitute for each other for practical purposes. Their empirical study identified five factors as strong determinants of job satisfaction such as achievement, recognition, work itself, responsibility and advancement. These factors are called motivators. Another group of factors that cause or prevent dissatisfaction are as follows: company policy and administration, technical aspects of supervision, salary, interpersonal relationships with superiors and working conditions. These factors are called hygiene factors.

\subsection{Organizational Commitment}

Newstrom and Davis's (1997) conception of organizational commitment is the degree to which an employee identifies with the organization and wants to continue active participation in it. They further stated that organizational commitment is a measure of willingness to remain with the firm in the future. It often reflects the employee's belief in the mission and goals of the firm, willingness to expend effort in their accomplishment, and intentions to continue working in the organization. Weiss and Cropanzano (1990) have identified commitment in three forms, they are affective commitment, continuance commitment and normative commitment. Affective commitment considers the person's emotional attachment to their organization. Continuance commitment is a person's perception of the costs and risks associated with leaving their current organization. Normative commitment is a morale dimension, based on a person's felt obligation and responsibility to their employing organization. Similarly, (Wood, 1996) defines organizational commitment is the degree to which a person strongly identifies with and feels a part of the organization in one of the significant study, Allen and Meyer (1990), tested the aspect of three components (affective, continuance and normative) model of organizational commitment that integrates various conceptualizations (affective attachment, perceived cost and obligation). The results revealed that the affective and continuance components of organizational commitment are empirically distinguishable constructs with different correlates. The affective and normative components, although distinguishable, appear to be somewhat related. Thus, the quality of the workplace is a vital factor in promoting organizational commitment. In contrast, good leadership and management may not guarantee committed employees. In a study Meyer and Allen (1991) have used affective, continuance and normative commitment to capture the multidimensional nature 
of organizational commitment, and among them comparatively affective commitment was considered to be a more effective measurement of organizational commitment. Meyer and Allen (1997) buttressed their stance for the importance of affective commitment by contending that employees with strong affective commitment would be motivated to higher levels of performance and make more meaningful contributions than employees who expressed continuance or normative commitment.

\subsection{Job Involvement}

Job involvement is the willingness of a person to work hard and apply effort beyond normal job expectations (Wood, 1996). Job involvement is the degree to which employees immerse themselves in their jobs, invest time and energy in them, and view work as a central part of their overall lives (Newstrom \&Devis, 1997). According to Singh and Rastogi (1981), job involvement results in an individual's tendency to exceed the normal expectation associated with his or her job. An employee with little job involvement will see it as just something to do to earn a living. Thus, all that motivates the worker is extrinsic making the employee to have little or no interest of learning how to perform the job better. On the other hand, a person with a lot of job involvement will derive intrinsic satisfaction from the job itself and will want to learn more and more about how to perform the job effectively. Job involved employees are likely to believe in the work ethic, to exhibit high growth needs, and to enjoy participation in decision making. As a result, they seldom will be tardy or absent, they are willing to work long hours and they will attempt to be high performers (Newstrom \& Davis, 1997).

\section{Research Context}

Established in 1980 in a community called Okyeso in Cape Coast Elmina highway as a community school, Archbishop Amissah memorial Catholic school was registered by the government in 1985. Back in Elmina, it was called Okyeso Catholic School. It was started near the road and with time the school was faced with insecurities as a result of vehicular movements. Based on that, Archbishop Amissah relocated the school to Duakro, hence its current location and was named after him. The school runs a Pre-school, Primary and Junior High School with two (2) attendants and fifteen (15) professional teachers and Ewe as the major Ghanaian language studied there simply because the community is inhabited by migrants from the Volta region in Ghana. The breakdown of both teaching and non-teaching staff is as follows, Kindergarten two (2) attendants and two (2) professional teachers; primary school consists of six (6) teachers and Junior high school seven (7) teachers including the head. In sum, the total number is employees are seventeen Flowers Gay Schools was established in 1980 with a population of three (3) students. This number increased by the end if term to thirteen (13) students. After 13years of providing quality service the school moved from third ridge where it commenced in a garage to its present location at West Adisadel near the industrial area. The breakdown of teaching and non-teaching staffs are as follows: Eight (8) Teaching Assistants, twelve (12) Non-teaching staffs, (36) Teaching staff, thirty-six, eight (8) internal managements, one (1) part time teacher, one (1) executive managements.

\subsection{Research design}

A research design is the basic plan, which directs the data collection and analysis of the research project. It is a framework which spells out the type of information to be collected, the sources of the data and data collection procedure. The research design used for the study was qualitative research design, specifically descriptive designs. The descriptive survey was chosen considering the purpose of the study.

\subsection{Population and sampling procedure}

The population used for the study consisted of eighty-three (83) employees both teaching and non-teaching staffs in Flowers Gay Schools and Okyeso Catholic School. Out the eighty- three employees, seventeen employees were from Okyeso Catholic School and sixty-six of them were from Flowers Gay Schools. The population helped to obtain a representative sample and was also accessible to the researcher. A sample is a subset of a population or a universe. Out of 83 respondents, s ample of thirty-nine (39) was used. The Newman format for determining the sample size was used to select the sample out of the population. With this, the principle is that smaller the population, the bigger the sample ratio. Due to this, one third (1/3) of the total population of sixty-six (66) was used for Flowers Gay Schools, hence a sample of twenty-two (22) was used and a census of seventeen (17) was used for Okyeso Catholic School. The sampling technique used for the study was probability sampling, specifically stratified sampling was used. This sampling technique was used because of the difference in the characteristics of the population of Flowers Gay Schools and Okyeso Catholic schools. Due to these variations, the population was divided into layers and each stratum was sampled separately.

\subsection{Sources, Data Collection and Processing}

The primary source includes the findings from the fieldtrip. The research primarily collected the data about employee attitude towards the organization. The primary sources were complemented by secondary data. 
Secondary data was elicited from the internet. These included publicized, unpublished documents such as books, manuscripts, reports, records, papers, and magazines were also used for the secondary data collection.

The aim of the study is to obtain information on the impacts of work-related attitude on employee performance at Flowers Gay Schools and Okyeso Basic School. Using questionnaire gave the researcher the opportunity to clarify and explain complex issues as majority can either read or write. This schedule is preferred because of its several advantages including enhancing researcher-respondents' relationship especially in explorative and descriptive studies such as this one. This helped in the systematic collection of the data. The tool needed for the data collection is questionnaire. The questionnaire will have thirty-one (31) questions which the respondents will have to answer. The reason for choosing the questionnaire for data collection is because respondents will find it easy answering the question by providing options for them rather than asking them to provide their own answers. And lesser time is required to answer the questions. The respondents express their views in a clear manner by the survey since the questionnaire contains both closed ended questions and open-ended questions. The interview questions were closed ended and open questions; they were put together in a form of questionnaires. These questionnaires were administered at Flowers Gay Schools and Okyeso Catholic School and recollected after the respondents provided their answers.

\section{Results and Discussions}

Questionnaires were distributed to 39 employees in the private sector and the public sector. Out of the 39 questionnaires, 22 were administered in the private sector and 17 were also administered at the public sector.

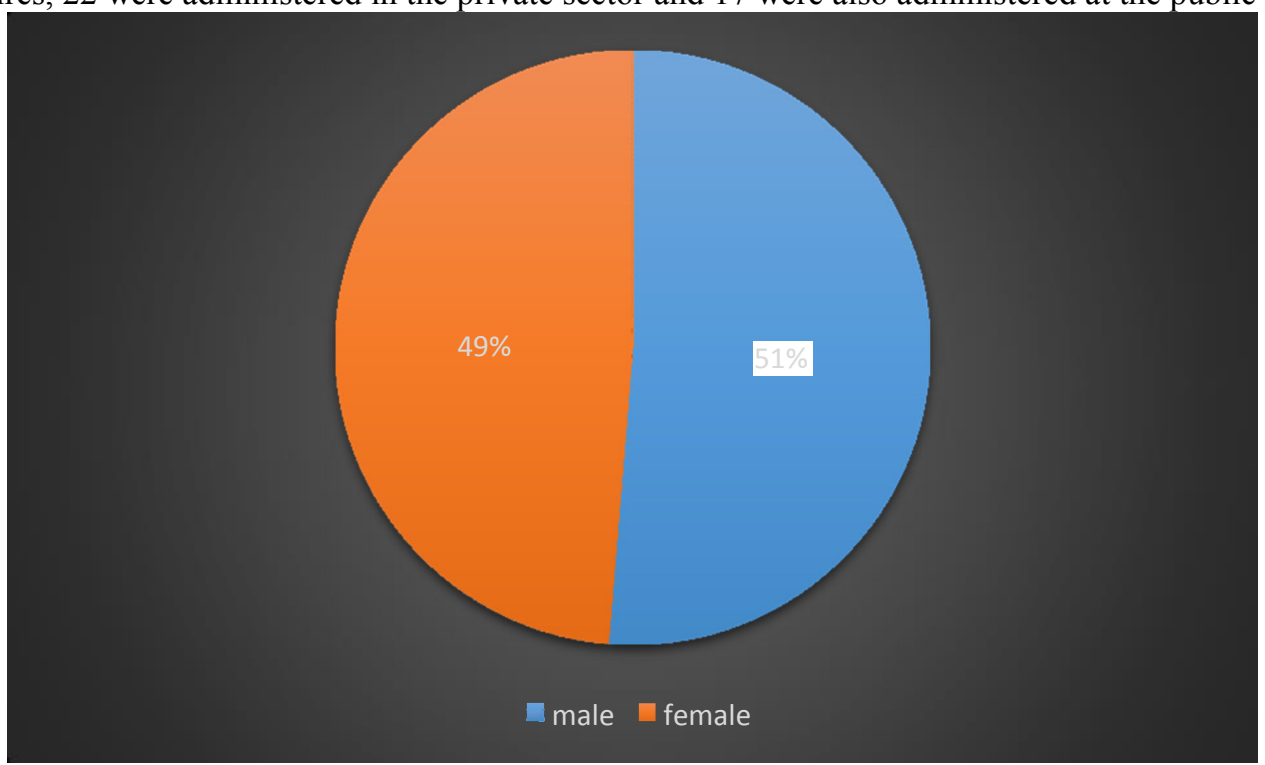

Figure 1: Gender of respondents

From fig 1, $51.3 \%$ of the respondents were male while $48.7 \%$ of the respondents were females. This trend shows male dominance over female dominance in both schools. 


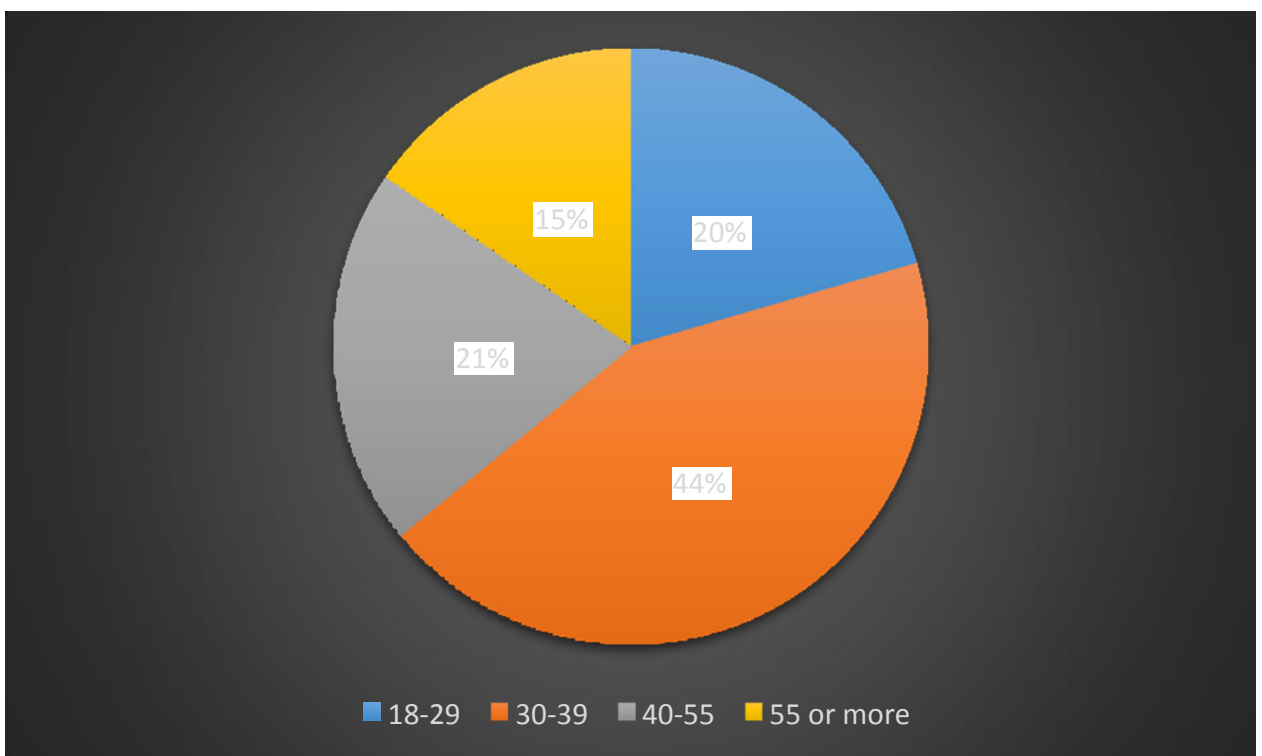

Figure 2: Ages of Respondents

Fig 2 above presents the age structure of the employees in the private sector and the public sector who were sampled for the study. A quick glance of the pie chart below indicates that $20.5 \%$ were between $18-29$ years, $43.6 \%$ were between 30-39 years, $20.5 \%$ of the respondents were also between $40-55$ years and $15.4 \%$ were 55 years and above. This trend is encouraging since the statistics indicates youthful employees in the study area.

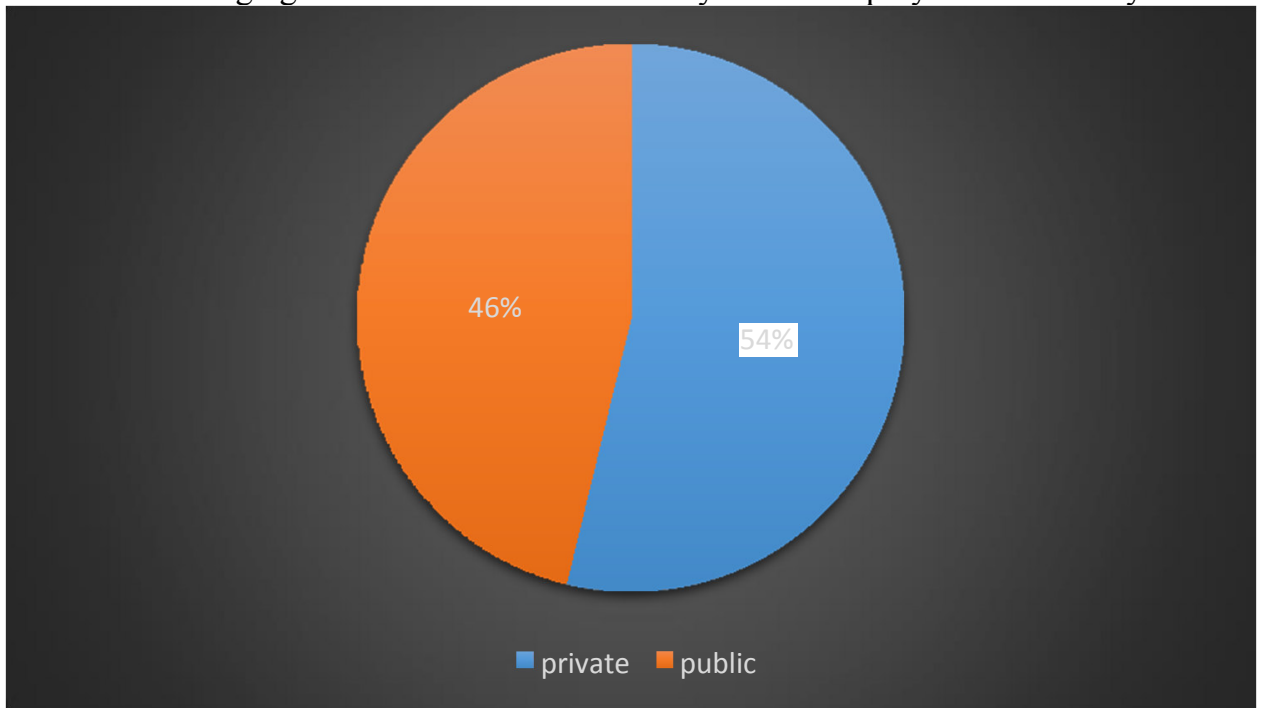

Figure 3: Type of institution

From fig 3 above, $54 \%$ of the respondents were from private sector while $46 \%$ of the respondents were from public sector. This shows that the private sector employs more people than the public sector as a result of division of labour. 


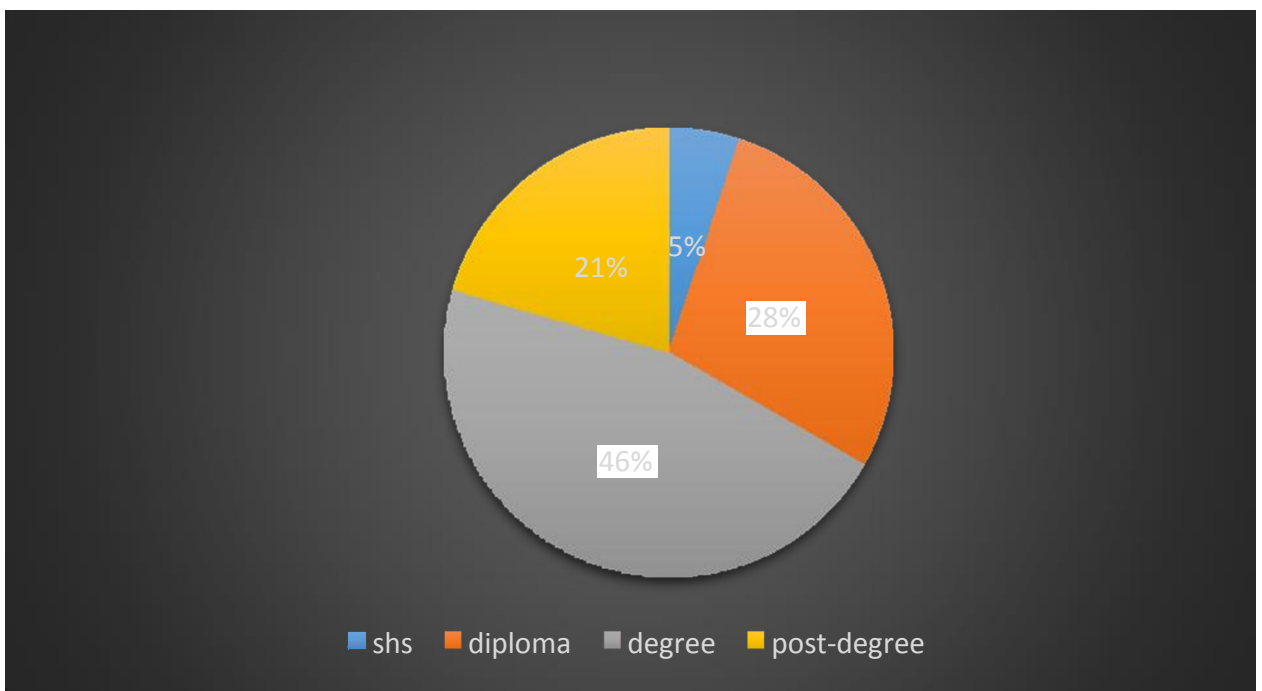

Figure 4: Level of Education of respondents

Education signifies one of the vital success factors that a company needs in order to succeed in their business activities. It provides the basis for academic development. A critical look of fig 4 above shows that $5 \%$ of the employees had attended secondary High school. $28 \%$ had training college/polytechnic education and $46 \%$ had University education, and $21 \%$ had post graduate degrees. This trend shows that both the private sector and the public sector had more of their employees being degree holders. It must be noted that high literate employees are essential incentives for organizational success.

Table 1: Department within Institutions

\begin{tabular}{lll}
\hline Department & Frequency & Percent \\
\hline Teaching & 29 & 74.4 \\
Non-Teaching & 5 & 12.8 \\
Administration & 4 & 10.3 \\
Other & 1 & 2.6 \\
\hline Total & 39 & 100.0 \\
\hline
\end{tabular}

\section{Source: Field Survey, 2018}

Table 1 above shows the various departments of private sector and public sector, (29) $74.4 \%$ belong to the teaching staff, (5) $12.8 \%$ are with non-teaching department, (4) 10.3\% are with the administration department, (1) $2.6 \%$ belongs to the other departments. This trend indicates that both institutions employ more of teaching staff than non-teaching staff. In addition, non- teaching staff plays an integral role in both institutions.

Table 2: Level of satisfaction of employees

\begin{tabular}{lllll}
\hline Response & $\begin{array}{l}\text { Private Sector } \\
\text { Frequency }\end{array}$ & Percent (\%) & $\begin{array}{l}\text { Public Sector } \\
\text { Frequency }\end{array}$ & Percent (\%) \\
\hline More satisfied & 2 & 9.09 & 2 & 11.76 \\
Satisfied & 16 & 72.73 & 14 & 82.35 \\
Less satisfied & 4 & 18.18 & 1 & 5.88 \\
\hline Total & $\mathbf{2 2}$ & & $\mathbf{1 7}$ & \\
\hline
\end{tabular}

\section{Source: Field Survey, 2018}

From table 2, 16(72.73\%) respondents from the private sector were satisfied with their work, $9.09 \%(2)$ respondents were more satisfied with their work, and $18.18 \%(4)$ were less satisfied with their work. In addition, $82.35 \%(14)$ respondents from the public sector were satisfied with their work, $11.76 \%(2)$ respondents were more satisfied with their work and $5.88 \%(1)$ respondent was less satisfied with his work. This simply implies that majority of employees in both the private and public sector of employment were satisfied with their work. A person with a high level of job satisfaction holds positive attitudes towards their job; a person who is dissatisfied with his or her job holds negative attitudes about the job (Robins, 2003). Workers will have high job satisfaction when they have positive attitudes toward such job factors such as the work itself, recognition and opportunity for advancement. According to Smith and Hulin (1969), job satisfaction is the extent to which a person is gratified or fulfilled by his or her work. 
Table 3: Level of job involvement

\begin{tabular}{lllll}
\hline Response & $\begin{array}{l}\text { Private Sector } \\
\text { Frequency }\end{array}$ & Percent (\%) & $\begin{array}{l}\text { Public Sector } \\
\text { Frequency }\end{array}$ & Percent (\%) \\
\hline Very high & 10 & 45.45 & 1 & 5.88 \\
High & 10 & 45.45 & 11 & 64.71 \\
Moderate & 2 & 9.09 & 5 & 29.41 \\
Low & 0 & 0 & 0 & 0 \\
\hline Total & $\mathbf{2 2}$ & $\mathbf{1 7}$ & & \\
\hline
\end{tabular}

Source: Field Survey, 2018

Table 3 shows that $45.45 \%(10)$ respondents in the private sector showed very high level of job involvement with the same number of respondents showing high level of job involvement in the same sector. 9.09\%(2) respondents also showed moderate level of job involvement. Almost all respondent showed some level of involvement in the job they did. Furthermore, 5.88\%(1) of respondents in the public sector showed very high level of job involvement, $64.71 \%(11)$ showed high level in job involvement and $29.41 \%(5)$ showed moderate levels in job involvement. This pattern clearly shows that most employees in the private sector of employment are highly involved in their work as compared to those in the public sector.

Table 4: Safety of work environment

\begin{tabular}{lllll}
\hline Response & Private Sector & Public Sector & \\
& Frequency & Percent (\%) & Frequency & Percent (\%) \\
\hline Very safe & 5 & 22.72 & 1 & 5.88 \\
Safe & 16 & 72.72 & 13 & 76.47 \\
Not Safe & 1 & 4.54 & 3 & 17.65 \\
\hline total & $\mathbf{2 2}$ & & $\mathbf{1 7}$ & \\
\hline
\end{tabular}

Source: Field Survey, 2018

From the responses in table 4, 22.72\%(5) of respondents in the private sector worked in a safer environment, $72.72 \%(16)$ respondents were safe in their work environment and 4.54\%(1) was not safe in his work environment. Also, $5.88 \%(1)$ respondents in the public sector were also safer, $76.47 \%(13)$ respondents were safe and $17.65 \%(3)$ were not safe with their work environment. This trend indicates that employees in the private sector of employment feel safer in their work environment than employees in the public sector. The presence of unsafe working conditions even in the presence of higher salaries can cause dissatisfaction and can induce employees to change jobs. Herzberg (1959) opined that in order to improve job attitudes and productivity, employers must attend to both factors and not assume that an increase in satisfaction leads to a consequential decrease in dissatisfaction.

Table 5: Motivation status among employees

\begin{tabular}{lllll}
\hline Response & $\begin{array}{l}\text { Private Sector } \\
\text { Frequency }\end{array}$ & Percent (\%) & \multicolumn{2}{c}{$\begin{array}{l}\text { Public Sector } \\
\text { Frequency }\end{array}$} \\
\hline Yes & 13 & 59.09 & 10 & Percent (\%) \\
No & 9 & 40.90 & 7 & 58.82 \\
\hline total & $\mathbf{2 2}$ & & $\mathbf{1 7}$ & 41.18 \\
\hline
\end{tabular}

Source: Field Survey, 2018

From table $5,59.09 \%(13)$ of respondents in the private sector were motivated on their jobs and $40.90 \%(9)$ respondents were not motivated on their jobs. On the contrary, 58.82\%(10) respondents in the public sector were motivated, however, $41.18 \%(7)$ respondents were not motivated on their jobs. This trend indicates that majority of employees in both private and public sector of employment are motivated on their job.

Table 6: Forms of motivation among employees

\begin{tabular}{lllll}
\hline $\begin{array}{l}\text { Forms of } \\
\text { Motivation }\end{array}$ & $\begin{array}{l}\text { Private Sector } \\
\text { Frequency }\end{array}$ & Percent (\%) & $\begin{array}{l}\text { Public Sector } \\
\text { Frequency }\end{array}$ & Percent (\%) \\
\hline Allowances & 10 & 45.45 & 2 & 11.64 \\
$\begin{array}{l}\text { Working Leave } \\
\text { On the }\end{array}$ & 2 & 9.09 & 5 & 29.41 \\
training & 1 & 4.54 & 0 & 0 \\
Awards & & & & 11.76 \\
Any other & 0 & 0 & 2 & 5.88 \\
\hline total & 0 & 0 & 1 & $\mathbf{1 7}$ \\
\hline
\end{tabular}

\section{Source: Field Survey, 2018}

From the responses in table $6,45.45 \%(10)$ of respondents in the private sector received motivation in the form of allowances, $9.09 \%(2)$, and $4.54 \%(1)$, also received motivations in the form of working leave, and on the job training respectively. Moreover, $11.64 \%$ (2) of the respondents in the public sector received allowances, 29.41\%(5), $11.76 \%(2)$, and $5.88 \%(1)$ of the respondents received motivation in the form of working leave, awards, and any 
other form of motivation respectively. Majority of employees in the private sector received allowances as forms of motivation more than those in the public sector, however employees in the public sector also had more working leave than employees in the private sector. Employees who are motivated tend to put up positive work attitude as compared to those who are less motivated.

Table 7: Rate of access to teaching and learning materials

\begin{tabular}{lllll}
\hline Response & $\begin{array}{l}\text { Private Sector } \\
\text { Frequency }\end{array}$ & Percent (\%) & $\begin{array}{l}\text { Public Sector } \\
\text { Frequency }\end{array}$ & Percent (\%) \\
\hline Very often & 5 & 22.72 & 5 & 29.41 \\
Often & 9 & 40.91 & 1 & 5.88 \\
Less often & 6 & 27.28 & 10 & 58.82 \\
Not at all & 2 & 9.09 & 1 & 5.88 \\
\hline total & $\mathbf{2 2}$ & & $\mathbf{1 7}$ & \\
\hline
\end{tabular}

\section{Source: Field Survey, 2018}

From table $7,22.72 \%(5)$ of respondents in the private sector had access to teaching and learning materials very often, $40.91 \%$ (9) and $27.28 \%$ (6), had access to learning and materials often times and at rare occasions respectively. $9.09 \%$ (2) had no access to learning and teaching materials. Also $29.41 \%$ (5) of respondents in the public sector had access to learning and teaching materials, 5.88\% (1), and 58.82\%(10) had access to learning and materials often times and at rare occasions respectively. $5.88 \%(1)$ had no access to learning and teaching materials. Teaching and learning materials were readily available for employees in the private sector than the employees in the public sector.

Table 8: Status of supervision among employees

\begin{tabular}{lllll}
\hline Response & Private Sector & Public Sector & \\
& Frequency & Percent (\%) & Frequency & Percent (\%) \\
\hline Yes & 20 & 90.91 & 17 & 100 \\
No & 2 & 9.09 & 0 & 0 \\
\hline total & $\mathbf{2 2}$ & & $\mathbf{1 7}$ & \\
\hline
\end{tabular}

Source: Field Survey, 2018

From the responses in table 8,90.91\%(20) of respondents in the private sector were supervised on their job and $9.09 \%(2)$ of the respondents indicated that they were not supervised on their job. Also $100 \%(17)$ of respondents in the public sector indicated that supervision was high as compared to respondents in the private sector

Table 9: Level of supervision among employees

\begin{tabular}{lllll}
\hline Response & $\begin{array}{c}\text { Private Sector } \\
\text { Frequency }\end{array}$ & Percent (\%) & Frequency & Percent (\%) \\
\hline Very effective & 13 & 59.09 & 5 & 29.41 \\
Effective & 7 & 31.82 & 9 & 52.94 \\
Less effective & 0 & 0 & 3 & 17.65 \\
\hline Total & $\mathbf{2 2}$ & & $\mathbf{1 7}$ & \\
\hline
\end{tabular}

\section{Source: Field Survey, 2018}

From table $9,59.09 \%$ (13) of respondents in the private sector indicated that supervision was very effective, $31.82 \%$ (7) indicated that supervision was effective. However, two (2) respondents said they were not supervised at all. In contrast, $29.41 \%$ (5) of respondents in the public sector indicated that supervision was more effective while 52.94\% (9) indicated that supervision was effective. Moreover, 17.65\% (3) showed that supervision was less effective. In a nutshell, despite the fact that supervision was hundred percent in the public sector as compared to $90.91 \%$ in the private sector, supervision was more effective in the private sector than in the public sector.

Table 10: Performance of students over the years in both private and public sector

\begin{tabular}{lllll}
\hline Response & Private Sector & Public Sector & \\
& Frequency & Percent (\%) & Frequency & Percent (\%) \\
\hline Excellent & 8 & 36.36 & 0 & 0 \\
Very good & 9 & 40.91 & 4 & 23.53 \\
Good & 5 & 22.73 & 13 & 76.47 \\
Poor & 0 & 0 & 0 & 0 \\
Total & $\mathbf{2 2}$ & & $\mathbf{1 7}$
\end{tabular}

\section{Source: Field Survey, 2018}

From table 10 above, $36.36 \%$ (8) respondents of employees in the private sector indicated that performance of students over the years is excellent. In addition, $40.91 \%(9)$ and $22.73 \%(5)$ indicated that performance of students is very good and relatively okay. On the contrary, $23.53 \%(4)$ and $76.47 \%(13)$ of respondents in the public sector indicated that performance of students over the years was very good and good respectively. This pattern 
clearly indicates that performance of students over the years is relatively high in the private sector that in the public sector.

\section{Findings}

The impact of work-related attitudes on performance in the private and public sector of employment has been an issue of critical concern. Previous research on this area established that positive work attitudes which include effective supervision, punctuality, and job satisfaction among employees are known to induce performance while negative work attitudes stifle performance and subsequent development of both the private and public sector of employment. In view of this, the study sought to do a research on the impact of work-related attitudes in the public and private sector of employment: A case study of Flowers Gay Schools and Okyeso Catholic School in Cape Coast Metropolis. Based on the data elicited from respondents and the analysis made, the following findings were made using research questions. With respect to job satisfaction, a major determinant of work attitudes in private and public sector of employment, employees in both private sector (Flowers Gay Schools) and public sector (Okyeso Catholic School) were satisfied with their work. Despite the fact that employees in both the private and public sector were satisfied with their work, employees in the private sector demonstrated high level of job involvement than employees in the public sector. In addition, job security is important if we are to understand work related attitudes on performance. As a result of this fact, it was seen from the research that employees in the private sector feel safer in their work environment than those in the public sector. However, in terms of motivation on their jobs, employees in both sectors were motivated on their job with allowances and working leave being the major forms of motivation. Furthermore, it was seen from the research that teaching and learning materials which are supposed to make work easier and induce employees to form positive work attitudes were readily available to employees in the private sector than their counterparts in the public sector. Based on this, employees in the private sector are likely to form positive work attitudes that will help stimulate performance than employees in the public sector.

Moreover, it was seen from the research that the issue of supervision was also different with respect to both sectors. Supervision was higher in the public sector than in the private sector. However, it was more effective in the private sector than in the public sector. This is to mean than mere supervision should not be used to measure job performance but effective supervision. The private sector demonstrated effective supervision and hence employees are likely to have positive work attitudes than those in the public sector. Finally, the research also revealed that student's performance in previous years has been higher in private sector than in the public sector. The high performance of students can partly be attributed to the fact that employees in the private sector, due to their favourable work attitudes are able to translate that to performance and the subsequent improvement at the workplace than employees in the public sector.

\section{Conclusion and Recommendations}

In summary, as seen from the analysis above, the study sought to indicate that work-related attitude can either be positive or negative. Positive work-related attitudes like job satisfaction, punctuality, adherence to work ethics among others are been triggered by effective supervision, motivation of employees and timely access to teaching and learning materials. On the contrary, negative work attitudes like absenteeism, high turnovers are present when supervision is not effective and teaching and learning materials are not made available and on time. Such contrast has been clearly presented in this research; the private sector employees showed high level of job involvement than those in the public sector, in addition, as a result of effective supervision, they showed more acceptable work attitudes than those in the public sector. This is to mean that mere supervision of employees does not translate to performance, but rather effective supervision of employees is what translates to performance among employees. Drawing inferences from the information gathered during the research, it was observed that the private and public sector of employment had some expectations that were yet to be met. In addition, improvement in both sectors had been stifled due to hosts of issues and this goes a long way to affect the performance of employees, particularly teachers, administrative staff and non- teaching staff. However, such measures that can be used to address such anomalies can be adequately addressed. Below are some recommendations to the ways that can be used to improve performance in both the private and public sector of employment. To begin with, the government must help address the problem of poor infrastructure in public schools. For the private school, the head of school must collaborate with the government, civil society organizations and non-governmental organizations to address the problem of poor infrastructure base. Infrastructure plays an integral role in most organizations and hence directly related to performance so it must be addressed to mitigate the problems besetting both sectors. In addition, teachers and other staff members cannot work properly if they are denied access to the materials are that will help them deliver. In short, there should be better and improved working conditions in order to help stimulate positive work attitudes and subsequently improved performance of workers. The provision of teaching and learning materials must be readily available in both sectors, especially public sector to make their work easy for them. The skills of employees can be upgraded by constantly providing them in-service training in order to help them cope with current work 
demands and diverse influence of the workplace.

Furthermore, in order to ensure that staff members work hard, there should be motivation and effective supervision of staff members. From information gathered from the research, it was seen that supervision exists in public sectors but entirely ineffective. Based on this, effective supervision is key if problems of poor performance will be addressed especially in the public sector. In the private sector too, despite the presence of effective supervision, it should be continued and well monitored in order to help staff members adhere to school's rules and regulations. Moreover, there should be efficient utilization of Parent Teacher Association (PTA) to address the concerns of the school. The PTA plays an integral role in most schools as they help in peaceful dialogue, procurement of materials and contribution of ideas. As a result of this fact, PTA meetings must be consistently organized to seek the views of parents, teachers and other stakeholders on how well to improve performance in the private school and public school.

\section{References}

Allen, N. J., \& Meyer, J. P. (1990). The measurement and antecedents of affective, continuance, and normative commitment to the organization. Journal of Occupational Psychology, 63, 1-18.

Amos, T.L., Ristow, A., \& Ristow, L. (2004). Human resource management (2nd ed.).Lansdowne: Juta and Co Ltd.

Bateman, T. \& Strasser, S. (1984). A longitudinal analysis of the antecedents of organizational commitment. Academy of Management Journal, 21, 95-112.

Brayfield. A.H \& Crockett, H.W (1955). Employee attitudes and employees' performance. Psychological Bulletion, $52,396-424$.

Bretz, R. D., \& Judge, T. A. (1994). The role of human resource systems in job applicant decision processes. Journal of Management, 20, 531-55.

Cole, M. (1996). Cultural psychology: A once and future discipline. Cambridge, MA: The Belknap Press.

Euske, K.J., Jackson, D.W., \& Reif, W.E. (1980). Performance and satisfaction of bank managers. Journal of Bank Research, 11(1), 36-42.

Fishbein, M., \& Ajzen, I. (1974). Attitudes towards objects as predictors of single and multiple behavioral criteria. Psychological Review, 81, 59-74.

Ghorpade, J., Lackritz, J. \& Singh, G. (2001). Work values and preferences for involvement of employees in the management of organizations. Paper presented at the Annual Conference of the Association of Employment Practices and Principles, San Francisco, USA, 18-20 October 2001.

Gibson, J.L., Ivancevich, J.M., \& Donnelly, J.H. (1991). Organizational behavior. Boston, MA: IRWIN Inc.

Greenberg, J., \& Baron, A. B. (2003). Behavior in organizations (8 ed.). Upper Saddle River, NJ: Prentice Hall.

Herzberg, F. (1959). Work and the nature of man. Cleveland: World Publishing Company.

Hackman, J.R., \& Oldham, G.R. (1976). Motivation through design of work. Journal of Organizational behavior and human performance, 16, 250-279.

Hulin, C.L.\& Smith, C.P. (1964). Sex differences in job satisfaction. Journal of Applied Psychology, 48(2), 88-92.

Jones, M. K., Jones, R. J., Latreille, P. L., \& Sloane, P. J. (2009). Training, job satisfaction, and workplace performance in Britain. Labour Journal, 23(1),139-175.

Judge, T. A., Thoresen, C. J., Bono, J. E. \& Patton, G. K. (2001). The job satisfaction job performance relationship: A qualitative and quantitative review. Psychological Bulletin, 127(3), 376-407.

Katz, D., \& Kahn, R. (1978). The social psychology of organizations (2nd ed.). New York, N.Y: Wiley.

Kreitner, R. \& Kinicki, A. (2004). Organisational behaviour (6th ed). New York, NY: McGraw- Hill.

Laffaladano, M.T., \& Muchinsky, P.M. (1985). Job satisfaction and job performance: A meta- analysis. Psychological Bulletin, 97, 251-273.

Lockheed, M. E., \& Verspoor, A. M. (1991). Improving education. Education Review16(3), 303- 311.

Locke, A. P., \& Weiss, H. M. (2001) Organizational behavior: Affect in the workplace. Annual Review of Psychology, 53, 279-307.

Mathieu, J. E., \& Zajac, D. (1990). A review and meta-analysis of the antecedents, correlates, and consequences of organizational commitment. Psychological Bulletin, 108, 171- 194.

Meyer, J. P., \& Herscovitch, L. (2001). Commitment in the workplace: Toward a general model. Human Resource Management Review, 11, 299-326.

Moorhead, G., and Griffin, R.W. (1999). Organizational behaviour: Managing People and Organization (3rd Ed.). Mumbai, India: Jaico Publishing House.

Mowday, R., Porter, L., \& Steers, R. (1982). Employee organization linkages: The psychology of commitment, absenteeism, and turnover. New York, N.Y: Academic Press.

Newstrom, J.W. \& Davis, K. (1993). Organizational behavior: Human behavior at work.

New York, NY: McGraw- Hill.

Neagley, R.I. \& Evans, N.D. (1970). Handbook for effective Supervisionof Intruction. Englewood Cliffs, N.Y: 
Prentice-Hull Inc.

Reichheld, F.F. (1993). Loyalty-based management. Harvard Business Review, 71(2), 64-73.

Robbins, S. P. (2003). Organisational behaviour: Global and Southern African perspectives. Cape Town, S.A: Pearson.

Robbins, S. P. (2005). Essentials of organisational behaviour. New Jersey, N.J: Pearson.

Saari, L.M., \& Judge, T. A. (2004). Employee attitudes and job satisfaction. Human Resource Management, 43 (4), 395-407.

Samad, S. (2011). The effects of job Satisfaction on organizational commitment and job performance relationship: A case of managers in Malaysia's manufacturing companies. European Journal of Social Sciences, 18(4), 602-611.

Singh, B., Gupta, P.K., \& Venugopal, S. (2008). Organizational commitment: Revisited, Journal of the Indian Academy of Applied Psychology, 34(1), 57-68.

Smith, C.A., Organ, D.W., \& Near, J.P. (1983). Organizational citizenship behavior: Its nature and antecedents. Journal of Applied Psychology, 68, 653-663.

Smith, P.C., Kendall, L.M., \& Hulin, C.L. (1969). The measurement of satisfaction in work and retirement. Chicago: Rand McNally.

Saari, L. M., \& Judge, T. A. (2002). Employee attitudes and job satisfaction. Journal of Human Resource Management, 43, 395-407.

Singh, P. G., \& Rastogi, M. (1981). Job involvement in relation to marital status and six psychological studies. Journal of personal management, 26(2),82 - 83.

Vanek, J. (1970). The general theory of labor managed market economies. Ithaca, NY: ILR Cornell University Press.

Vroom, V.H., \& Deci, E. L. (1970). Management and motivation. New York, N.Y: Penguin Books Limited.

Vroom, V. H. (1964). Work and motivation. New York, N.Y: Wiley.

Weiss, H. M., \& Cropanzano, R. (1996). Affective events theory: A theoretical discussion of the structure, causes and consequences of affective experiences at work. Research in Organizational Behavior, 18, 1-74 